\title{
Five New Small-sized Species of the Genus Cybaeus (Araneae: Cybaeidae) from the Chugoku District, Honshu, Japan
}

\author{
Yoh IHARA $^{1)}$ \\ 井原 庸 ${ }^{1)}$ ：中国地方産小型ナミハグモ（クモ目：ナミハグモ科） \\ の 5 新種
}

\begin{abstract}
Five new species of the spider genus Cybaeus are described from the Chugoku district, western Honshu, Japan, under the names C. hiroshimaensis, gonokawa, tsurusakii, nojimai, and okayamaensis. These species are relatively small (2.5-3.5 $\mathrm{mm}$ in body length) and resemble each other in the general appearances, although each of them can be clearly distinguished from the other by their structures of male palp and female genitalia. Their distributions are allopatric or parapatric with each other. They can be considered as members of a single superspecies or a closely related species-group.
\end{abstract}

About 40 species of the genus Cybaeus have been recorded from Japan. However, their taxonomy is still far from complete and there are many undescribed species even in the main islands of Japan. I have been involved in a survey of geographic variations of the group in Chugoku district, western Honshu, Japan, for several years. During the survey, I have found several undescribed species of Cybaeus, each of which often has a very limited distributional area. Of those, I will describe here five new species as the first report of my survey.

All the new species have relatively small size (2.5-3.5 $\mathrm{mm}$ in body length) compared to other species of Cybaeus and resemble each other in general appearances. Furthermore, they share following characteristics which may represent synapomorphic states: 1) a tunnel web with three retreats (Y-shaped nest) rather than that with two retreats in other Japanese species of Cybaeus; 2) relatively short tibia of male palp which is almost as long as patella; 3) tibia of 2nd legs with 2-2-1 (retromargin) -0 ventral spines and 2 prolateral spines. These facts and their distributions, showing allopatric or parapatric patterns with each other, suggest that they constitute a single monophyletic species group which may correspond to one superspecies. In the other Japanese species of Cybaeus, C. ishikawai (KomATSU), nishikawai (KOMATSU), anaiwaensis (KOMATSU) and kompiraensis (KoMATSU), all of which have been recorded from Kochi Pref., Shikoku, are known to make a tunnel web with three retreats (Komatsu, 1968). Therefore, it is possible that these species

1) Yagi 5-27-13-203, Asaminami-ku, Hiroshima, 731-01 Japan

干731-01 広島市安佐南区八木 5 丁目 27-13-203

Accepted November 8, 1993 
and the new species are close to each other.

The type and voucher specimens are deposited in the National Science Museum (Natural History), Tokyo. Other specimens are in my personal collection.

Abbreviations used: KN, Kôichi NoJima; YI, Yoh IHARA.

\section{Cybaeus hiroshimaensis sp. nov.}

(Figs. 1-7)

\section{Description.}

Male (holotype). Measurements (in $\mathrm{mm}$ ). Body length 3.3; carapace length 1.64, width 1.12 ; abdomen length 1.5 , width 1.2 ; sternum length 0.80 , width 0.78 . Length of legs as shown in Table 1.

Carapace relatively short, ratio of width to length 0.68 . Cephalic region rather short and gradually narrowed anteriorly (Fig. 1). Anterior eye row slightly procurved as seen from front, posterior eye row almost straight as seen from above. Anterior median eyes smallest, diameter about one-third to the others. The other eyes subequal. Ocular area twice as wide as long. Clypeus as long as length of median ocular area. Chelicera nearly vertical, with unnoticeable lateral condyle, and both margins of fang furrow with teeth. Sternum almost as long as wide, anterior margin almost straight. Labium wider than long, 1.4: 1 in ratio. Length of legs: $4 \fallingdotseq 1>2>3$. Tibia I with $2-2-2-1$ (promargin) ventral spines and 2 prolateral spines; metatarsus I with 2-2-2 ventral spines and 1 prolateral spine; tibia II with $2-2-1$ (retromargin) -0 ventral spines and 2 (right) or 3 (left) prolateral spines; metatarsus II with 2-2-3 ventral spines and 1 prolateral spine.

Palp (Figs. 2-5). Rather short and stout, tibia short and almost as long as patella (except for apophysis). Patella with a long prolateral apophysis, the apex pointed. Genital bulb circle. Conductor simple, the apex pointed.

Coloration. Carapace orange yellow with a pale heart-shaped marking, and posterior half paler. Chelicerae, maxillae, labium and sternum orange yellow, sternum paler than the others. Legs orange yellow, femora paler than the others, without annulation. Spines of legs reddish brown. Abdomen uniformly pale yellow.

Female. Measurements (in $\mathrm{mm}$; one of the paratypes). Body length 3.4 ; carapace length 1.46 , width 0.98 ; abdomen length 2.0 , width 1.5 ; sternum length 0.72 , width 0.68 . Length of legs as shown in Table 2.

Similar to male in coloration. Carapace more slender, abdomen larger and more rounded, legs shorter than those of male.

Genitalia (Figs. 6-7). Epigynum simple, medially with a transverse atrial slit,

Table 1. Length of legs of Cybaeus hiroshimaensis sp. nov., $\sigma^{7}$ holotype (in $\mathrm{mm}$ ).

\begin{tabular}{lcccccc}
\hline Leg & $\mathrm{Fe}$ & $\mathrm{Pa}$ & $\mathrm{Ti}$ & $\mathrm{Mt}$ & $\mathrm{Ta}$ & Total \\
\hline I & 1.20 & 0.48 & 1.04 & 0.90 & 0.72 & 4.34 \\
II & 1.10 & 0.48 & 0.90 & 0.86 & 0.62 & 3.96 \\
III & 0.98 & 0.46 & 0.66 & 0.80 & 0.54 & 3.44 \\
IV & 1.16 & 0.44 & 1.04 & 1.08 & 0.64 & 4.36 \\
\hline
\end{tabular}



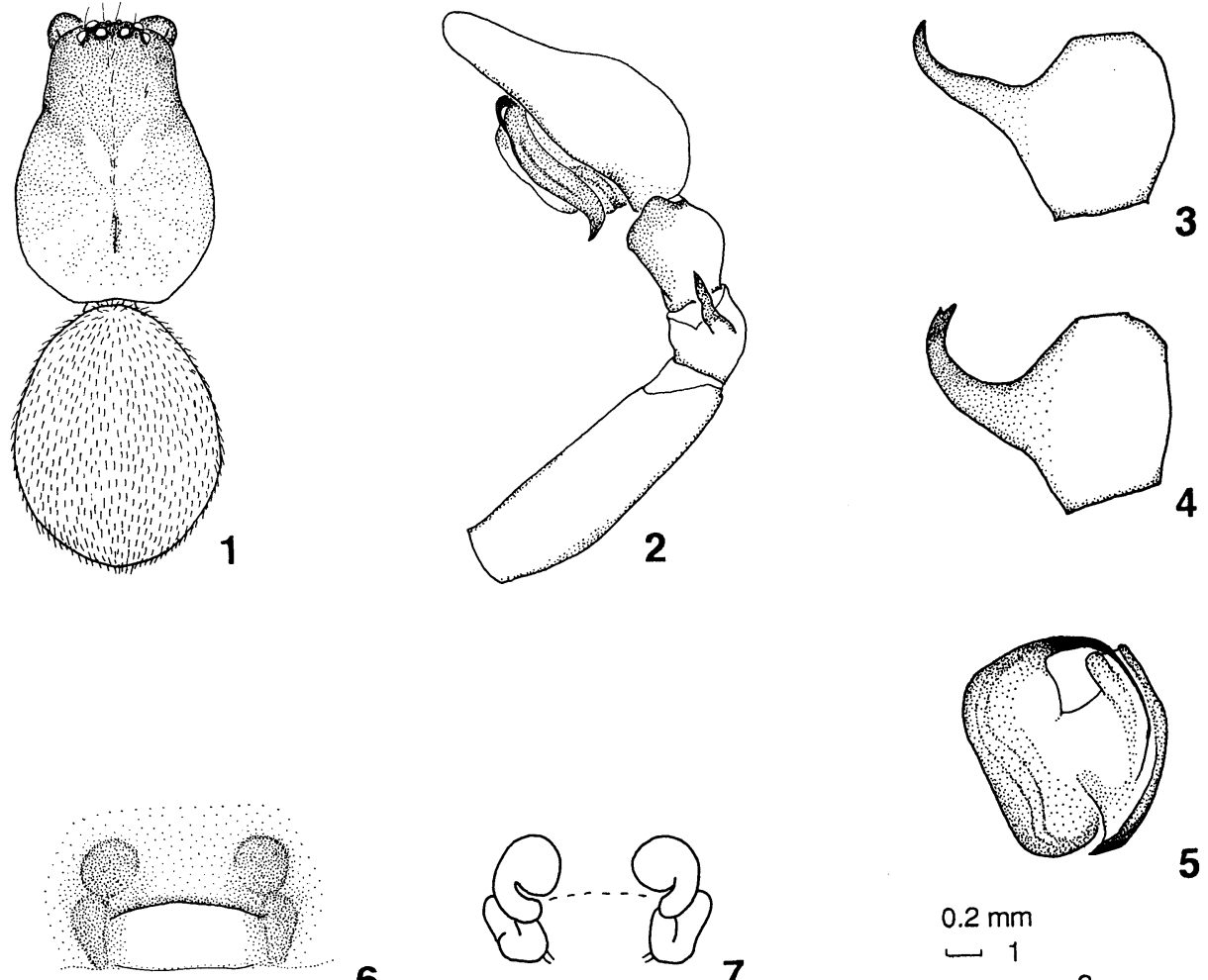

6

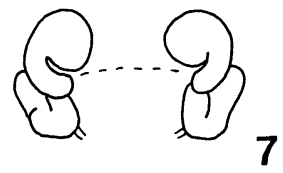

5
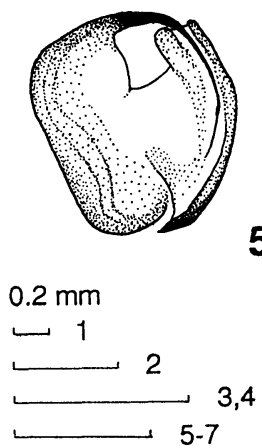

Figs. 1-7. Cybaeus hiroshimaensis sp. nov. —— 1, Male body, dorsal view. 2-5, Left male palp: 2, retrolateral view; 3-4, patella, dorsal view; 5, apical part of the bulb, ventral view. 6-7, Female genitalia: 6, epigynum, ventral view; 7, internal structure, dorsal view. (1-3, 5, holotype; 6-7, paratype; 4, male from Mt. Motsutagadake.)

Table 2. Length of legs of Cybaeus hiroshimaensis sp. nov., 1 우 paratype (in $\mathrm{mm}$ ).

\begin{tabular}{lcccccc}
\hline Leg & Fe & Pa & Ti & Mt & Ta & Total \\
\hline I & 1.00 & 0.46 & 0.82 & 0.72 & 0.52 & 3.52 \\
II & 0.90 & 0.42 & 0.72 & 0.68 & 0.46 & 3.18 \\
III & 0.78 & 0.36 & 0.54 & 0.64 & 0.44 & 2.76 \\
IV & 0.98 & 0.40 & 0.82 & 0.84 & 0.50 & 3.54 \\
\hline
\end{tabular}

internal structure discernible through the integument. Internal genitalia as shown in Fig. 7.

Variation. Body size (in $\mathrm{mm}$, male $\mathrm{n}=32$, female $\mathrm{n}=56$. No significant differences among populations): Body length, 2.6-3.5 (mean 3.08, SD 0.220) in male, 2.7-4.2 (mean 3.32, SD 0.342) in female; carapace length, 1.42-1.70 (mean 1.59, 
SD 0.071) in male, 1.24-1.72 (mean 1.53, SD 0.102) in female; carapace width, 1.001.18 (mean 1.11, SD 0.047) in male, 0.82-1.14 (mean 1.02, SD 0.068) in female.

Males of populations from Geihoku mountains (westernmost area of Hiroshima Pref.) and the westward (Fig. 27) have a bifurcated prolateral apophysis of patella (Fig. 4) instead of one having a single apex (Fig. 3).

Coloration of abdomen varies from pale yellow to grayish yellow.

Specimens examined. Type series. Holotype ( $\left.\sigma^{7}\right)$ and paratypes (10 8우), 3-V-1991, YI; Mt. Gokurakuji, Hatsukaichi-shi, Hiroshima Pref. Japan.

Voucher specimens for geographic variation of male. $20^{7} 4$ 우, Mt. Motsutagadake, Muikaichi-chô, Kanoashi-gun, Shimane Pref., 10-XII-1989, KN.

Other specimens. YAMAGUCHI PREF.: Mine-gun, Akiyoshi-chô, Yunokami, 4o 5우, 12-X-1991, YI. Abu-gun, Abu-chô, Mt. Shirasu, 1우, 10-XII-1989, KN. Saba-gun, Tokuchi-chô, Mitani, 10 2우, 2-XI-1990, YI. Shin-nan-yô-shi, Wada, 10`, 12-X-1991, YI. HIROSHIMA PREF.: Saeki-gun: Saiki-chô, Shibao, 10 $0^{\top}$ 2우, 29-I-1989, YI; Yoshiwa-son, Hachirô, 1우, 6-X-1991, YI; Yuki-chô, Uchiodani, 20`, 21-I-1990, YI; Yuki-chô, Mt. Ômine, 10', 22-IX-1990, Megumi IHARA. Yamagata-gun: Geihoku-chô, Mt. Garyû, 1우, 5-X-1989, YI; 20 2우, 24-IX-1990, YI; 1우, 5-V-1991, YI; 1우 6-V-1991, YI; Togôchi-chô, Sakane, 1우, 28-X-1989, YI; Kake-chô, Masahara, 1ㅇ, 18-III-1990, YI; Toyohira-chô, Hiura, 20주웅, 21-III-1990, YI. Hiroshima-shi, Asakita-ku: Nabara Gorge, $10^{\top} 1$ 우, 8-I1989, YI; Uga Gorge, 1우, 5-II-1989, YI; Shiraki-chô, Ichikawa, 1우, 19-X-1992, YI. Toyota-gun, Yasuura-chô, Mt. Noro, 10 2우, 4-XI-1991, YI. Takata-gun: Yachiyo-chô, Haji Dam, 1우, 11-II-1990, YI; Midori-chô, Chikyôji, 1우, 4-III1990, YI; Yoshida-chô, Kôchi, 2ㅇ, 9-XII-1990, YI; Mukaihara-chô, Sen-nichi,

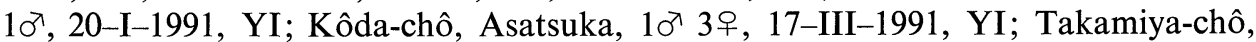

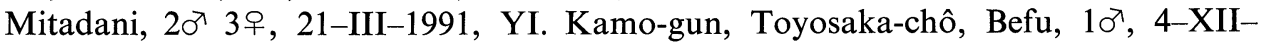
1990, YI. Miyoshi-shi: Arihara-chô, 1ㅇ, 10-III-1991, YI; Shiwachi, 1우, 5-IV1992, YI. Futami-gun: Kimita-son, Kôbo Dam, 2우, 15-X-1989, M. IHARA; Funoson, Yokotani, 20ำ1우, 26-X-1991, YI. Fukuyama-shi, Ryûzu Gorge: 1우, 23-IX1989, YI; $10^{\top} 1$ 우, 31-XII-1989, KN; 1워 1우, 31-XII-1989, YI. Jinseki-gun, Yukichô, Aotaki, 10', 10-XI-1991, YI. SHIMANE PREF.: Mino-gun, Mito-chô, Hisahara, 10 1우, 22-X-1992, YI. Naka-gun, Asahi-chô, Ichiki, 2우, 28-X-1990, YI. Iishi-gun, Akagi-chô, Nondani, $10^{7}$ 2우, 21-X-1990, YI.

Distribution. Yamaguchi Pref., Hiroshima Pref. and western part of Shimane Pref., western Honshu (Fig. 27).

Remarks. Males of this species resemble those of $C$. tsurusakii, but can be distinguished from them by having a more slender apophysis with no teeth on its palpal patella.

Cybaeus gonokawa sp. nov.

(Figs. 8-14)

Description.

Male (holotype). Measurements (in $\mathrm{mm}$ ). Body length 3.4; carapace length 1.76 , width 1.16 ; abdomen length 1.8 , width 1.4 ; sternum length 0.84 , width 0.82 . Length of legs as shown in Table 3.

Carapace relatively short, ratio of width to length 0.67 . Cephalic region rather 
Table 3. Length of legs of Cybaeus gonokawa sp. nov., o7 holotype (in mm).

\begin{tabular}{lcccccc}
\hline Leg & $\mathrm{Fe}$ & $\mathrm{Pa}$ & $\mathrm{Ti}$ & $\mathrm{Mt}$ & $\mathrm{Ta}$ & Total \\
\hline I & 1.32 & 0.52 & 1.14 & 1.04 & 0.76 & 4.78 \\
II & 1.26 & 0.52 & 0.98 & 0.96 & 0.68 & 4.40 \\
III & 1.10 & 0.48 & 0.76 & 0.88 & 0.58 & 3.80 \\
IV & 1.34 & 0.48 & 1.16 & 1.22 & 0.70 & 4.90
\end{tabular}
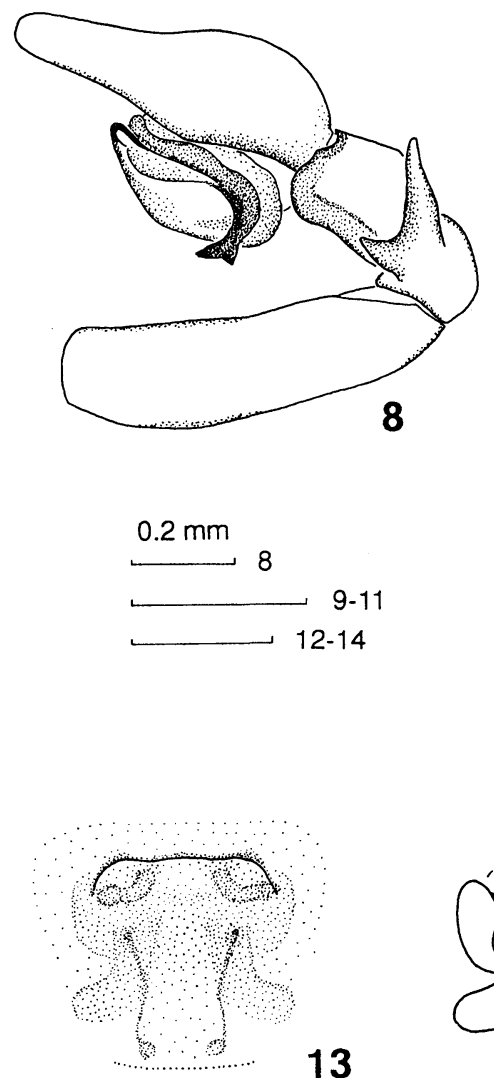

13

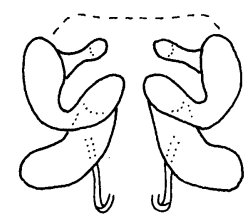

14
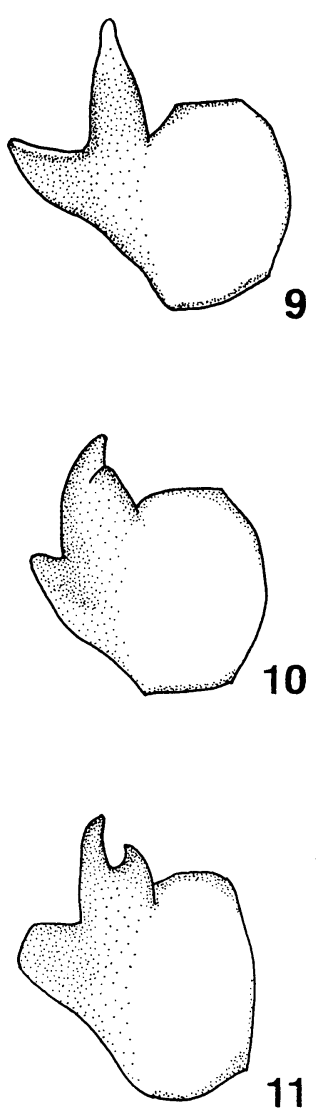

Figs. 8-14. Cybaeus gonokawa sp. nov. - 8-12, Left male palp: 8, retrolateral view; 9-11, patella, dorsal view; 12, apical part of the bulb, ventral view. 13-14, Female genitalia: 13, epigynum, ventral view; 14, internal structure, dorsal view. $(8-9,12$, holotype; 13-14, paratype; 10, male from Nichihara, Daiwa-son; 11, male from Tani, Sakurae-chô.)

short and gradually narrowed anteriorly. Eyes similar to those of $C$. hiroshimaensis. Clypeus shorter than length of median ocular area, 0.9:1 in ratio. Chelicera and sternum similar to those of $C$. hiroshimaensis. Labium wider than long, 1.4: 1 in 
Table 4. Length of legs of Cybaeus gonokawa sp. nov., 1우 paratype (in mm).

\begin{tabular}{lcccccc}
\hline Leg & Fe & Pa & Ti & Mt & Ta & Total \\
\hline I & 1.10 & 0.48 & 0.90 & 0.80 & 0.52 & 3.80 \\
II & 1.02 & 0.48 & 0.78 & 0.70 & 0.52 & 3.50 \\
III & 0.90 & 0.40 & 0.58 & 0.64 & 0.48 & 3.00 \\
IV & 1.10 & 0.44 & 0.92 & 0.94 & 0.54 & 3.94 \\
\hline
\end{tabular}

ratio. Length of legs $4>1>2>3$, leg IV slightly longer than leg I. Tibia I with 2-2-2-0 ventral spines and 2 prolateral spines; metatarsus I with $2-2-2$ ventral spines and 1 prolateral spine; tibia II with $2-2-1$ (retromargin) -0 ventral spines and 2 prolateral spines; metatarsus II with $2-2-3$ ventral spines and 2 (left) or 3 (right) prolateral spines.

Palp (Figs. 8-12). Rather short and stout, tibia short and almost as long as patella (except for apophysis). Patella laterally with a large bifurcated apophysis. Genital bulb oval. Conductor with a small triangular apophysis.

Coloration. Carapace light yellowish brown, anterior half darker. Chelicerae, maxillae and labium yellowish brown. Sternum light yellowish brown. Legs light yellowish brown, without annulation. Spines of legs dark brown. Abdomen grayish yellow and dorsally with some pale spots.

Female. Measurements (in $\mathrm{mm}$; one of the paratypes). Body length 3.6; carapace length 1.64 , width 1.08 ; abdomen length 1.9 , width 1.4 ; sternum length 0.80 , width 0.76 . Length of legs as shown in Table 4.

Similar to male in coloration. Carapace more slender, abdomen larger and more rounded, legs shorter than those of male.

Genitalia (Figs. 13-14). Epigynum simple, anteriorly with a transverse atrial slit, internal structure visible through the integument. Internal genitalia as shown in Fig. 14.

Variation. Body size (in $\mathrm{mm}$, male $\mathrm{n}=9$, female $\mathrm{n}=22$ ): Body length, 2.9-3.5 (mean 3.26, SD 0.171) in male, 3.0-4.0 (mean 3.52, SD 0.237) in female; carapace length, 1.52-1.82 (mean 1.74, SD 0.087) in male, 1.40-1.88 (mean 1.63, SD 0.110) in female; carapace width, $1.10-1.28$ (mean 1.21, SD 0.060) in male, 0.92-1.22 (mean 1.07, SD 0.071) in female.

Shape of patellal apophysis of male palp considerably varies among populations (Figs. 9-11).

Specimens examined. Type series. Holotype $\left(0^{7}\right)$ and paratypes $\left(40^{7}\right), 26-\mathrm{X}-$ 1991, YI, paratypes (6우), 21-III-1991, YI; Yachiyo Falls, Funo-son, Futami-gun, Hiroshima Pref., Japan.

Voucher specimens for geographic variation. $10^{7} 1$ 우, Tani, Sakurae-chô, Ôchi-gun, Shimane Pref., 28-X-1990, YI. $10^{\top} 1$ 우, Nichihira, Daiwa-son, Ôchi-gun, Shimane Pref., 28-X-1990, YI.

Other specimens. HIROSHIMA PREF.: Miyoshi-shi, Yamaga-chô: 1우, 3-IV-1990, YI; 2우, 8-IV-1990, YI; 10', 5-X-1990, YI. Futami-gun: Funo-son, Binzaka, 1오, 26-X-1991, YI; Sakugi-son, Jôsei Falls, 3우, 21-III-1991, YI. SHIMANE PREF.: Ôchi-gun: Sakurae-chô, Senjô Valley, 10', 28-X-1990, YI; Kawamotochô, Chikushihara, 1우, 28-X-1990, YI; Daiwa-son, Ueno, 1우, 4-III-1990, YI, 
107 2오, 30-IX-1990, YI; Ôchi-chô, Hananotani, 1우, 19-III-1993, YI. Ôda-shi, Mt. Sanbe, 2우, 24-III-1991, YI. Iishi-gun, Kakeya-chô, Hata, 1우, 24-III-1991, YI. Distribution. Hiroshima Pref. (Miyoshi-shi and Futami-gun) and central part of Shimane Pref., western Honshu. Found along the Gônokawa basin (Fig. 27).

Remarks. Shape of male palp and female genitalia are characteristic.

Etymology. The specific epithet is a noun in apposition.

Cybaeus tsurusakii sp. nov.

(Figs. 15-18)

\section{Description.}

Male (holotype). Measurements (in mm). Body length 3.5; carapace length 1.72 , width 1.28 ; abdomen length 1.8 , width 1.3 ; sternum length 0.82 , width 0.84 . Length of legs as shown in Table 5.

Carapace relatively short, ratio of width to length 0.74 . Cephalic region rather short and gradually narrowed anteriorly. Eyes similar to those of $C$. hiroshimaensis. Clypeus as long as the length of median ocular area. Chelicera similar to C. hiroshimaensis. Sternum slightly wider than long, anterior margin straight. Labium wider than long, 1.6: 1 in ratio. Lengths of legs: $4>1>2>3$. Tibia I with 2-2-2-0 ventral spines and 2 prolateral spines; metatarsus $I$ with $2-2-2$ ventral spines and 1 prolateral spine; tibia II with $2-2-1$ (retromargin) -0 ventral spines and 2 prolateral spines; metatarsus II with 2-2-3 ventral spines and 2 prolateral spines.

Palp (Figs. 15-16). Rather short and stout, tibia short and almost as long as patella (except for apophysis). Patella with a long apophysis; the apophysis anteriorly with a tooth. Genital bulb oval. Conductor well developed, with a hooked apophysis.

Coloration. Carapace yellowish brown, slightly shaded with gray. Chelicerae, maxillae, labium and sternum yellowish brown, chelicerae darker than the others. Legs yellowish brown, without annulation. Spines of legs reddish brown. Abdomen grayish yellow and dorsally with some pale spots.

Female. Measurements (in mm; paratype). Body length 3.4; carapace length 1.72 , width 1.20 ; abdomen length 1.8 , width 1.4 ; sternum length 0.82 , width 0.80 . Length of legs as shown in Table 6.

Similar to male in coloration. Carapace more slender, abdomen larger and more rounded, legs shorter than those of male.

Genitalia (Figs. 17-18). Epigynum simple, medially with a transverse atrial slit. Internal structure pentagon, discernible through the integument. Internal

Table 5. Length of legs of Cybaeus tsurusakii sp. nov., ơ holotype (in mm).

\begin{tabular}{lcccccc}
\hline Leg & Fe & Pa & Ti & Mt & Ta & Total \\
\hline I & 1.24 & 0.48 & 1.12 & 0.98 & 0.66 & 4.48 \\
II & 1.20 & 0.50 & 0.94 & 0.90 & 0.62 & 4.16 \\
III & 1.04 & 0.44 & 0.70 & 0.86 & 0.56 & 3.60 \\
IV & 1.28 & 0.46 & 1.08 & 1.18 & 0.66 & 4.66 \\
\hline
\end{tabular}


Table 6. Length of legs of Cybaeus tsurusakii sp. nov., 1 우 paratype (in mm).

\begin{tabular}{lcccccc}
\hline Leg & Fe & Pa & Ti & Mt & Ta & Total \\
\hline I & 1.20 & 0.52 & 1.00 & 0.84 & 0.56 & 4.12 \\
II & 1.12 & 0.50 & 0.86 & 0.84 & 0.56 & 3.88 \\
III & 0.94 & 0.46 & 0.68 & 0.80 & 0.46 & 3.34 \\
IV & 1.20 & 0.46 & 1.02 & 1.08 & 0.54 & 4.30 \\
\hline
\end{tabular}

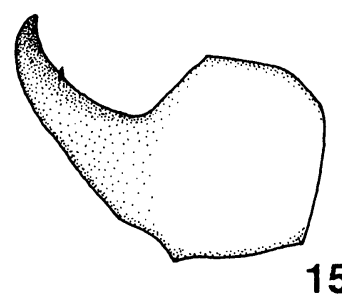

15
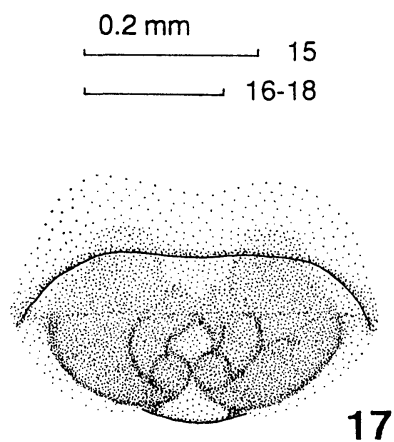

17

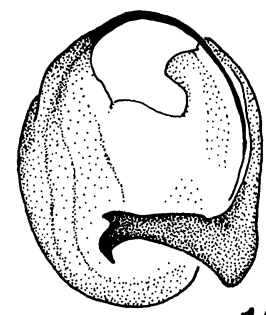

16

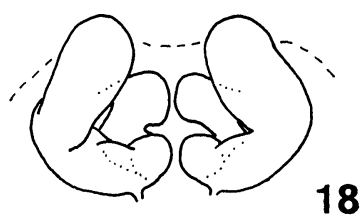

Figs. 15-18. Cybaeus tsurusakii sp. nov. _ 15-16, Left male palp: 15, patella, dorsal view; 16, apical part of the bulb, ventral view. 17-18, Female genitalia: 17, epigynum, ventral view; 18, internal structure, dorsal view. (15-16, holotype; 17-18, paratype.)

genitalia as shown in Fig. 18.

Variation. Body size (in $\mathrm{mm}$, male $\mathrm{n}=7$, female $\mathrm{n}=31$ ): Body length, $3.1-3.5$ (mean 3.33, SD 0.128) in male, 2.8-4.5 (mean 3.50, SD 0.435) in female; carapace length, $1.56-1.74$ (mean 1.68, SD 0.058) in male, 1.30-1.82 (mean 1.61, SD 0.128) in female; carapace width, $1.18-1.30$ (mean 1.27, SD 0.040) in male, 0.90-1.24 (mean 1.11, SD 0.081) in female.

Specimens examined. Type series. Holotype $\left(\sigma^{\top}\right)$ and paratype (우), 18-X1992, YI; Mt. Ôyorogi, Tonbara-chô, Iishi-gun, Shimane Pref., Japan.

Other specimens. HIROSHIMA PREF.: Hiba-gun: Takano-chô, Mt. Yubitani, 1우, 5-V-1989, YI; Kuchiwa-chô, Takechi-dani, 1우, 8-VI-1991, YI; Hiwa-chô, Mt. Azuma, 3우, 12-XI-1990, YI; Saijô-chô, Kumano Shrine 1우, 10-X-1989, YI, 1우, 16-VI-1990, YI, 1우, 1-XI-1991, Nobuo TsurusaKI; Saijô-chô, Mt. Kenashi, 
1우, 1-XI-1991, N. Tsurusaki. SHIMANE PREF.: Same locality as for the holotype, 1우, 21-X-1990, YI. Iishi-gun: Tonbara-chô, Kusandawa Pass, 1우, 23XI-1989, YI; Kakeya-chô, Yae Falls, 1ㅇ, 24-III-1991, YI. Hikawa-gun, Hikawachô: Gakutô, 1우, 7-IX-1990, YI; 1우, 8-IX-1990, YI; Kanba, 3우, 17-III-1993, YI; 4우, 26-III-1993, YI. Ôhara-gun Kisugi-chô, Mano, 20', 15-XI-1991, YI. Yatsuka-gun, Higashiizumo-chô, Konpira Shrine, 10 1우, 14-XI-1991, YI. Nitagun, Yokota-chô: Mt. Sentsû, 20 4우, 12-XI-1989, YI, 1우, 23-IX-1991, YI; Sakane, 2ㅇ, 14-IV-1991, YI. OKAYAMA PREF.: Maniwa-gun, Shinjô-son, Mt. Kenashi, 1우, 20-V-1990, KN, 10 1우, 21-X-1990, KN.

Distribution. Northeastern part of Hiroshima Pref. (Hiba-gun), eastern part of Shimane Pref. and northwestern part of Okayama Pref., western Honshu (Fig. 27).

Remarks. Refer to the "Remarks" in C. hiroshimaensis about male palp. Female genitalia are characteristic. versity.

Etymology. The specific name is after Dr. Nobuo TsurusaKI, Tottori Uni-

\section{Cybaeus nojimai sp. nov.}

(Figs. 19-22)

\section{Description.}

Male (holotype). Measurements (in $\mathrm{mm}$ ). Body length 2.6; carapace length 1.46, width 1.10 ; abdomen length 1.4 , width 0.9 ; sternum length 0.70 , width 0.72 . Length of legs as shown in Table 7.

Carapace relatively short, ratio of width to length 0.75 . Cephalic region rather short and gradually narrowed anteriorly. Eyes similar to those of $C$. hiroshimaensis. Ocular area wider than long, 1.9: 1 in ratio. Clypeus almost as long as length of median ocular area. Chelicerae similar to those of $C$. hiroshimaensis. Sternum slightly wider than long, anterior margin slightly undulate. Labium wider than long, 1.3: 1 in ratio. Length of legs $4>1>2>3$, leg IV slightly longer than leg I. Spination of legs same as in C. tsurusakii.

Palp (Figs. 19-20). Rather short and stout, tibia short and almost as long as patella. Patella prolaterally with two short apophysis and a tooth. Genital bulb circle. Conductor thick, the apex swollen.

Coloration. Carapace orange yellow. Chelicerae, maxillae, labium and sternum orange yellow, sternum paler than the others. Legs orange yellow without annulation. Spines of legs reddish brown. Abdomen uniformly pale yellow.

Female. Measurements (in $\mathrm{mm}$; one of the paratypes). Body length 3.1; carapace length 1.44 , width 0.96 ; abdomen length 1.6 , width 1.3 ; sternum length

Table 7. Length of legs of Cybaeus nojimai sp. nov., ơ holotype (in $\mathrm{mm}$ ).

\begin{tabular}{lcccccc}
\hline Leg & $\mathrm{Fe}$ & $\mathrm{Pa}$ & $\mathrm{Ti}$ & $\mathrm{Mt}$ & $\mathrm{Ta}$ & Total \\
\hline I & 1.00 & 0.40 & 0.80 & 0.74 & 0.54 & 3.48 \\
II & 0.94 & 0.40 & 0.70 & 0.68 & 0.50 & 3.22 \\
III & 0.80 & 0.36 & 0.56 & 0.66 & 0.46 & 2.84 \\
IV & 1.00 & 0.40 & 0.80 & 0.90 & 0.52 & 3.62 \\
\hline
\end{tabular}


Table 8. Length of legs of Cybaeus nojimai sp. nov., 1우 paratype (in mm).

\begin{tabular}{lcccccc}
\hline Leg & Fe & Pa & Ti & Mt & Ta & Total \\
\hline I & 0.92 & 0.44 & 0.74 & 0.66 & 0.46 & 3.22 \\
II & 0.82 & 0.42 & 0.64 & 0.60 & 0.44 & 2.92 \\
III & 0.70 & 0.36 & 0.48 & 0.56 & 0.40 & 2.50 \\
IV & 0.92 & 0.36 & 0.74 & 0.80 & 0.48 & 3.30 \\
\hline
\end{tabular}
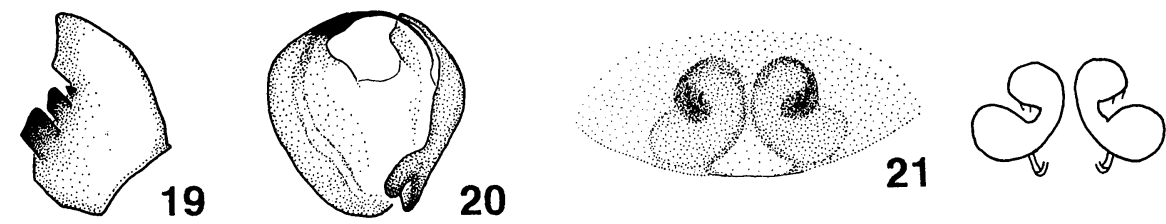

Figs. 19-22. Cybaeus nojimai sp. nov. ——19-20, Left male palp: 19, patella, retrolateral view; 20, apical part of the bulb, ventral view. 21-22, Female genitalia: 21, epigynum, ventral view; 22, internal structure, dorsal view. (19-20, holotype; 21-22, paratype.)

0.68, width 0.68. Length of legs as shown in Table 8 .

Similar to male in coloration. Carapace more slender, abdomen larger and more rounded, legs shorter than male.

Genitalia (Figs. 21-22). Epigynum simple, medially with a pair of openings of genital atria, internal structure perceptible through the integument. Internal genitalia as shown in Fig. 22.

Variation. Body size (in $\mathrm{mm}$, male $\mathrm{n}=10$, female $\mathrm{n}=15$ ): Body length, 2.6-3.2 (mean 2.92, SD 0.214) in male, 2.9-3.7 (mean 3.29, SD 0.270) in female; carapace length, 1.46-1.76 (mean 1.55, SD 0.099) in male, 1.26-1.62 (mean 1.47, SD 0.110) in female, carapace width, $1.06-1.30$ (mean 1.14, SD 0.077) in male, $0.88-1.14$ (mean 1.01 , SD 0.081) in female.

Specimens examined. Type series. Holotype (o') and paratypes (10 3 우), 29-X-1990, KN; Mt. Yamanori, Chûka-son, Maniwa-gun, Okayama Pref., Japan.

Other specimens. OKAYAMA PREF.: Maniwa-gun: Chûka-son, Tsuguro Highlands, 207, 9-X-1990, KN; Yubara-chô, Shirane Valley, 10`, 19-XI-1989, KN. Tomata-gun: Kamisaibara-son, Onbara Highlands, 1우, 12-XI-1989, KN. Kamochô, Aoyagi, 1우, 6-II-1990, KN. Katsuta-gun, Nagi-chô, Mt. Takiyama: 10', 22-X-1989, KN; 2우, 17-VI-1990, KN. Aida-gun: Nishiawakura-son, Wakasugi, 10', 12-XI-1989, KN, 1우, 2-VI-1990, KN; Higashiawakura-son, Mt. Ushiroyama, 1우, 3-VI-1990, KN. TOTTORI PREF.: Tottori-shi, Momodani Shrine, 1우, 14III-1992, N. TsuruSAKI. Yazu-gun: Kawahara-chô, Kitamura, 10 1우, 14-X-1990, KN, 207' 14-X-1990, YI; Mochigase-chô, Akanami, 2ㅇ, 23-X-1991, YI. HYOGO PREF.: Sayô-gun, Sayô-chô, Kuchibase, 3우, 3-V-1993, YI.

Distribution. Northeastern part of Okayama Pref., eastern part of Tottori 
Pref. and northwestern part of Hyogo Pref., western Honshu (Fig. 27).

Remarks. Male palp and female genitalia are characteristic.

Etymology. The specific name honors Mr. Kôichi NoJIMA, Okayama, who first collected the specimens.

\section{Cybaeus okayamaensis sp. nov.}

(Figs. 23-26)

\section{Description.}

Male (holotype). Measurements (in $\mathrm{mm}$ ). Body length 3.2; carapace length 1.60 , width 1.12 ; abdomen length 1.6 , width 1.2 ; sternum length 0.76 , width 0.72 . Length of legs as shown in Table 9.

Carapace relatively short, ratio of width to length 0.70 . Cephalic region rather short and gradually narrowed anteriorly. Eyes similar to those of $C$. hiroshimaensis, but diameter of anterior median eye less than one-third to the others. Clypeus as long as length of median ocular area. Chelicera similar to that of $C$. hiroshimaensis. Sternum longer than wide, anterior margin straight. Labium wider than long, 1.6: 1 in ratio. Length of legs: $4>1>2>3$. Spination of legs same as in C. tsurusakii.

Palp (Figs. 23-24). Rather short and stout, tibia short and almost as long as patella. Patella prolaterally with a spatula-like apophysis. Genital bulb circle. Conductor thick and long.

Coloration. Carapace orange yellow, posterior half paler, and slightly shaded with gray. Chelicerae, maxillae, labium and sternum orange yellow, sternum paler than the others. Legs yellowish brown without annulation. Spines of legs reddish brown. Abdomen grayish yellow.

Female. Measurements (in $\mathrm{mm}$ : one of the paratypes). Body length 3.1; carapace length 1.42 , width 0.96 ; abdomen length 1.8 , width 1.3 ; sternum length 0.70 , width 0.68 . Length of legs as shown in Table 10 .

Similar to male in coloration. Carapace more slender, abdomen larger and

Table 9. Length of legs of Cybaeus okayamaensis sp. nov., $\sigma^{7}$ holotype (in mm).

\begin{tabular}{lcccccc}
\hline Leg & Fe & Pa & Ti & Mt & Ta & Total \\
\hline I & 1.12 & 0.44 & 0.92 & 0.82 & 0.60 & 3.90 \\
II & 1.06 & 0.42 & 0.82 & 0.80 & 0.52 & 3.62 \\
III & 0.88 & 0.36 & 0.62 & 0.76 & 0.54 & 3.16 \\
IV & 1.12 & 0.40 & 0.94 & 1.02 & 0.62 & 4.10 \\
\hline
\end{tabular}

Table 10. Length of legs of Cyabeus okayamaensis sp. nov., 1 우 paratype (in mm).

\begin{tabular}{lcccccc}
\hline Leg & $\mathrm{Fe}$ & $\mathrm{Pa}$ & $\mathrm{Ti}$ & $\mathrm{Mt}$ & $\mathrm{Ta}$ & Total \\
\hline I & 0.94 & 0.40 & 0.78 & 0.68 & 0.44 & 3.24 \\
II & 0.88 & 0.40 & 0.70 & 0.66 & 0.40 & 3.04 \\
III & 0.76 & 0.36 & 0.54 & 0.62 & 0.40 & 2.68 \\
IV & 0.96 & 0.38 & 0.78 & 0.86 & 0.52 & 3.50 \\
\hline
\end{tabular}




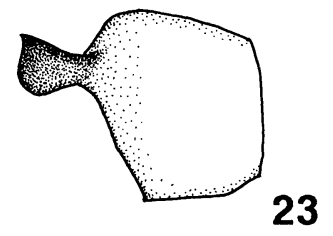

$0.2 \mathrm{~mm}$ 23

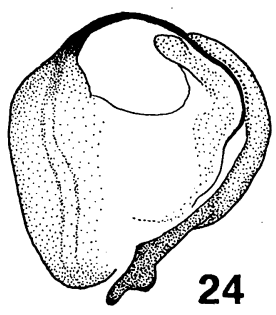

24-26
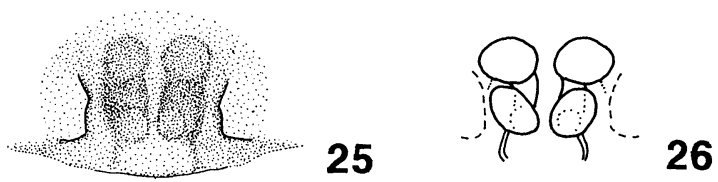

Figs. 23-26. Cybaeus okayamaensis sp. nov. —-23-24, Left male palp: 23, patella, dorsal view; 24, apical part of the bulb, ventral view. 25-26, Female genitalia: 25, epigynum, ventral view; 26, internal structure, dorsal view. (23-24, holotype; 25-26, paratype.)

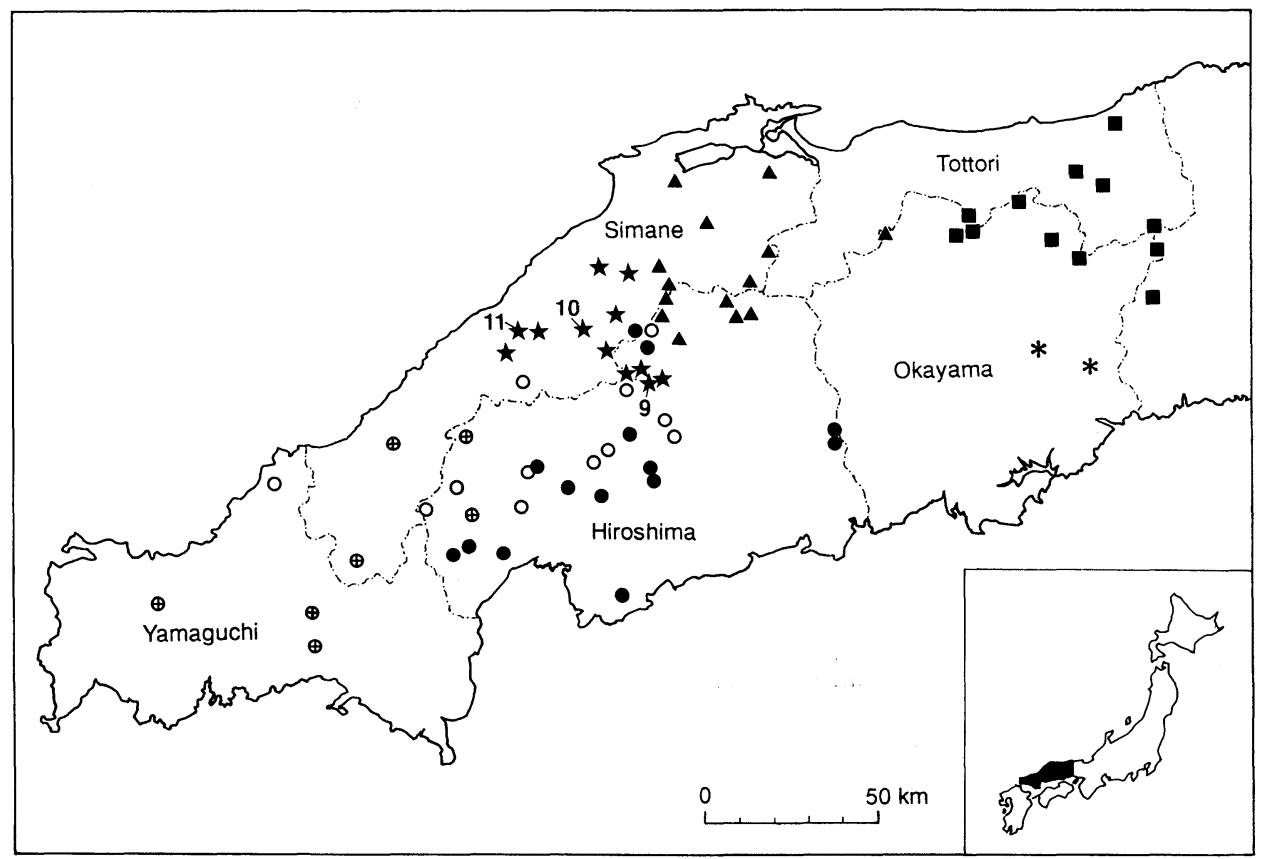

Fig. 27. Distribution of five species of Cybaeus. Circles: C. hiroshimaensis; populations with male palpal patellae shown in Fig. 3 (solid) and in Fig. 4 (crossed); open circles denote populations where males are unknown. Stars: C. gonokawa; populations with numerals (9-11) denote sources of materials described in Figs. 9-11. Triangles: C. tsurusakii. Squares: C. nojimai. Asterisks: C. okayamaensis. 
more rounded, legs shorter than those of male.

Genitalia (Figs. 25-26). Epigynum simple; A pair of genital atria opens at relatively remote positions with each other, the internal structure visible through the integument. Internal genitalia as shown in Fig. 26.

Variation. Body size (in mm, female $\mathrm{n}=4$ ): Body length, 2.8-3.4 (mean 3.18); carapace length, 1.32-1.42 (mean 1.37); carapace width, 0.88-0.96 (mean 0.92).

Specimens examined. Type series. Holotype (ठ), 18-X-1992, paratypes (3우), 28-III-1993, KN; Oze, Yanahara-chô, Kume-gun, Okayama Pref., Japan.

Other specimens. Ôfuji, Yoshinaga-chô, Wake-gun, Okayama Pref., 1우, 29-X-1992, KN.

Distribution. Southeastern part of Okayama Pref., western Honshu (Fig. 27).

Remarks. Shape of patellae of male palps and female genitalia are unique and serve to the identification of the species.

\section{Acknowledgments}

I wish to express my hearty thanks to Dr. Nobuo Tsurusaki, Tottori University, for his constant guidance, offering specimens and reading the manuscript of this paper, and to Mr. Kôichi NoJIMA, Okayama, for his offering many invaluable specimens used in this study. My thanks are also due to Mrs. Megumi IHARA, for her support especially in field collectings of the specimens.

\section{摘 要}

本州中国地方産の Cybaeus（ナミハグモ属）の 5 新種, C. hiroshimaensis アキコガタナ ミハグモ (新称), C. gonokawaイワミコガタナミハグモ(新称), C. tsurusakii イズモコ ガタナミハグモ (新称), C. nojimai ノジマコガタナミハグモ (新称), C. okayamaensis キ ビコガタナミハグモ（新称）を記載した。これらの種は体のサイズや形態がよく似てお り, 互いに近縁であると考兄られる. また, 分布は異所的または側所的で, その分布状況 を示した。

\section{References}

Komatsu, T., 1968. Cave spiders of Japan. II Cybaeus Dolichocybaeus and Heterocybaeus (Cybaeinae). $38 \mathrm{pp.} \mathrm{Arachnological} \mathrm{Society} \mathrm{of} \mathrm{East} \mathrm{Asia,} \mathrm{Osaka.}$ 